\title{
Syntheses and application of phosphates containing nitrogen.
}

\author{
Makoto WATANABE, Yoshiki SHIONOYA, Makoto SAKURAI and Mioko MAEDA \\ Department of Applied Chemistry, College of Engineering, Chubu University, 1200 Matsumoto-cho, \\ Kasugai, Aichi 487-8501, Japan
}

\begin{abstract}
$\underline{\text { Abstract }}$
Electric conductivity of phosphate compounds with nitrogen was measured in order to use the materials for cogeneration type of fuel cell system, because the compounds have possibility to use as a new solid electrolyte. We used melamine orthophosphate (MOP), melamine pyrophosphate(MDP) and melamine polyphosphate(MPP) as melamine phosphates, and ammonium polyphosphate forms I (APP I ), II (APP II) and $\mathrm{V}(\mathrm{APP} \mathrm{V})$ as ammonium polyphosphates. The conductivity of the materials was measured by impedance analyzer. The conductivity of MDP with mixture ratio of diammonium hydrogen phosphate : melamine $=1: 1$ and prepared at $200^{\circ} \mathrm{C}$ was $6 \times$ $10^{-4} \mathrm{~S} / \mathrm{cm}$ and was the highest value at $200^{\circ} \mathrm{C}$.
\end{abstract}

\section{INTRODICTION}

Consumption of fossil fuel causes a lot of environmental pollution including global warming of living area. Environmental problem is growing up more and more seriously. We have to develop a new energy system quickly to improve environmental conditions. ${ }^{1}$ The fuel cell has great possibilities. Tablel shows some types of fuel cell systems. Solid electrolytes which work at a moderately high temperature $\left(200 \sim 500^{\circ} \mathrm{C}\right)$ are not studied well. This type of electrolytes has possibilities to use in a cogeneration system, application to an electrochemical hydrogen pump and hydrogen sensor. This study aims to develop a fuel cell which works at moderately high temperature. An inorganic proton conductor such as a heat-resistant macromolecule and a metal oxide is effective to operate the fuel cell at $100 \sim 300^{\circ} \mathrm{C}$. It is expected that a phosphates with high condensation degree with containing nitrogen are effective as materials satisfying this demand. We used a various phosphorus nitrogen compounds in this experiment and measured their conductivity at a moderately high temperature. 
Tablel. Some types of fuel cell

\begin{tabular}{|c|c|c|c|c|c|}
\hline & Alkaline & $\begin{array}{c}\text { Phosphoric } \\
\text { acid }\end{array}$ & $\begin{array}{c}\text { Proton exchange } \\
\text { membrane }\end{array}$ & $\begin{array}{c}\text { Molten } \\
\text { carbanete }\end{array}$ & Solid oxide \\
\hline Electrolyte & $\mathrm{KOH}$ & Phosphate & $\begin{array}{c}\text { high polymer } \\
\text { film }\end{array}$ & $\begin{array}{c}\text { Molten } \\
\text { carbanete }\end{array}$ & $\begin{array}{c}\text { Yttria Stabilized } \\
\text { Zirconia }\end{array}$ \\
\hline $\begin{array}{c}\text { Operation } \\
\text { temperature } \\
\left({ }^{\circ} \mathrm{C}\right)\end{array}$ & 100 & 200 & 100 & 650 & 1000 \\
\hline fuel & $\begin{array}{c}\text { high purity } \\
\text { hydrogen }\end{array}$ & hydrogen & hydrogen & hydrogen & hydrogen \\
\hline $\begin{array}{c}\text { Power } \\
\text { generation } \\
\text { efficiency }\end{array}$ & $60 \%$ & $35 \sim 45 \%$ & $40 \%$ & $45 \sim 55 \%$ & $50 \%$ \\
\hline use & $\begin{array}{c}\text { Special } \\
\text { environment } \\
\text { (space, deep sea })\end{array}$ & $\begin{array}{c}\text { cogeneration } \\
\text { (bus) }\end{array}$ & car & $\begin{array}{c}\text { cogeneration } \\
\text { (large scale) }\end{array}$ & $\begin{array}{c}\text { cogeneration } \\
\text { (middle scale) }\end{array}$ \\
\hline
\end{tabular}

\section{EXPERIMENTAL}

The phosphate compounds containing nitrogen of melamine orthophosphate (MOP), melamine pyrophosphate (MDP), melamine polyphosphate (MPP) and ammonium polyphosphates (APP) of forms I, II and V were prepared according to usual process. ${ }^{2}$ Disks of these powder samples with $1 \mathrm{~mm}$ thickness were prepared. These samples were coated by $\mathrm{Au}$ on the surface of both sides. Electric conductivity was measured by impedance meter. Composition of raw materials was examined to improve electric conductivity. A mixture of diammonium orthophosphate and melamine with mixing molar ratio of $1: 1$ was heated at $220 \sim 280^{\circ} \mathrm{C}$ for 2 hours. A mixture of diammonium orthophosphate and melamine of mixing ratio of $1: 1$ to $1: 0.5$ were heated at $200^{\circ} \mathrm{C}$ for 2 hours.

\section{RESURT AND DISCUTION}

The conductivity of APP forms I, II and V were measured at $100^{\circ} \mathrm{C}$, and the conductivity was $9 \times 10^{-5}, 6.7 \times 10^{-8}$ and $5 \times 10^{-5} \mathrm{~S} / \mathrm{cm}$, respectively. APP showed high conductivity, but these compounds were not able to use at $200{ }^{\circ} \mathrm{C}$ because the compounds decomposed at the temperature. The conductivities of MOP and MDP were measured at $200^{\circ} \mathrm{C}$, and were $2.6 \times 10^{-9}$ 
and $7.9 \times 10^{-5} \mathrm{~S} / \mathrm{cm}$, respectively. The conductivity of MPP was measured at $200^{\circ} \mathrm{C}$, and it was $6.3 \times 10^{-5} \mathrm{~S} / \mathrm{cm}$. MDP showed the highest conductivity. The conductivity of MDP was dependent on reaction temperature and mixing ration of diammonium phosphate and melamine.

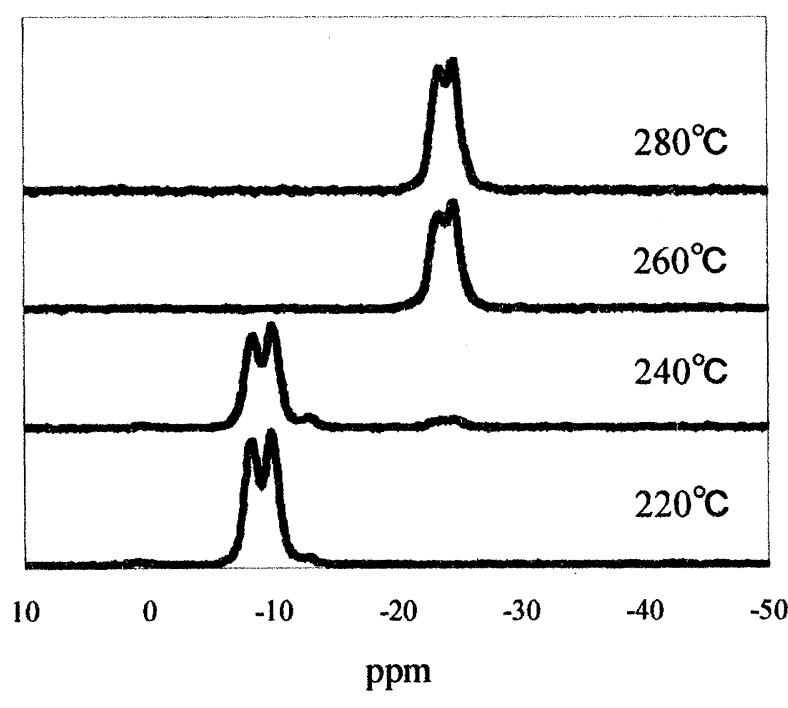

Fig1. ${ }^{31} \mathrm{P}$ MAS NMR of melamin pyrophosphate

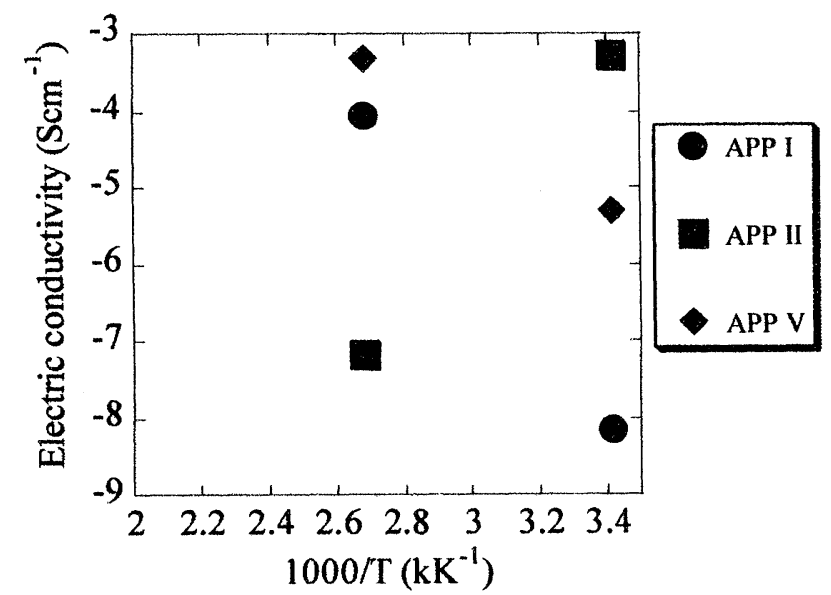

Fig3. Electric conductivity of APPs

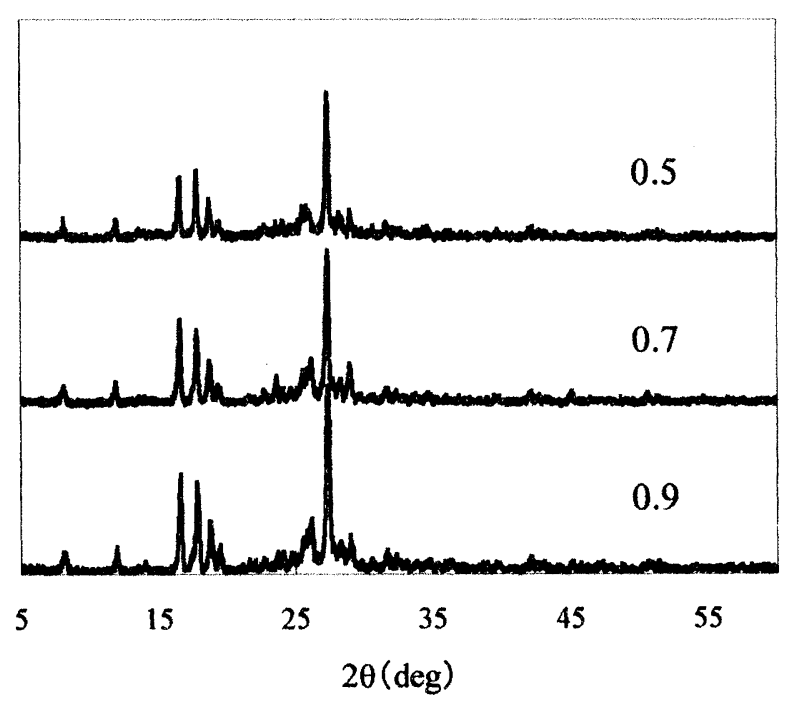

Fig2.Xray diagrams of melamin pyrophosphate

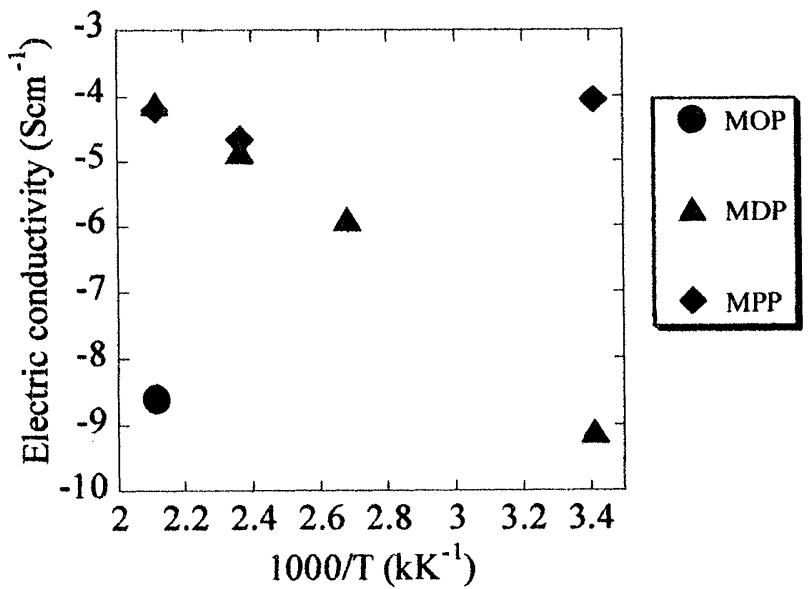

Fig4. Electric conductivity 


\section{REFEREMCES}

1. Edited by Chem. Soc. JPN, "kagaku to kogyo" Vol. 56-8, 857(2003).

2. M. Watanabe, M. Watanabe, N. Narita, M. Sakurai and H. Suzuki, Bull Chem. Soc. Jpn., 73, 115(2000) and papers cited therein. 